\title{
ASSESSMENT OF TECHNICAL FACULTIES STUDENTS' ACADEMIC ACHIEVEMENTS DURING THE STUDY OF ENGLISH
}

TSYMBAL S. V., Doctor in Psychology, Associate Professor of the Department of English for Technical and Agrobiological Specialities

National University of Life and Environmental Sciences of Ukraine

E-mail: s.vtsymbal@nubip.edu.ua

ORCID ID: 0000-0003-0652-369X

YAREMENKO N. V. , PhD in Pedagogy, Associate Professor of the Department of English for Technical and Agrobiological Specialities

National University of Life and Environmental Sciences of Ukraine

E-mail: iaremenko.nv@gmail.com

ORCID ID: 0000-0002-5894-0295

Abstract. The article deals with the approaches of the organization of control of educational achievements of students of technical faculties during the study of English and presents their own experience in its implementation. It is established that for the effective organization of the educational process it is necessary to evaluate the work of students both during practical classes and their independent work systematically. During pedagogical activity it is established that during the current control it is expedient to organize preliminary and thematic control. When exercising control, it is necessary to take into account the correctness of the answers, the completeness of the disclosure of educational material and the independence of the task. Moreover, we note that there are different levels of knowledge acquisition, namely: the level of understanding; level of knowledge; level of reproductive action; level of productive action; level of creative action. Current control can take place in two ways: in the form of frontal control or individual control, orally or in writing, depending on the purpose of the inspection. It was found that no less important attention should be paid to the organization of control of independent work of students, which is aimed at testing the acquisition of both theoretical knowledge and work with oral topics. The final control in English includes both open (provided questions to which the student must provide a detailed answer) and closed (choose the correct answer) tests.

Key words: students, control, current control, final control.

Introduction. One of the necessary conditions for the organization of successful student learning is effective control of their academic achievements and instilling in students the skills of selfcontrol, because these activities can identify and eliminate gaps in knowledge and consolidate the material studied. At the same time, it can be argued that the control of students' academic achievements also creates conditions for student development and significantly stimulates independent work. That is why the issue of organizing the control of educational activities has repeatedly attracted the attention of scientists.

Analysis of recent research and publications has shown that scientists have repeatedly addressed this scientific problem. In particular, theoretical aspects of the organization of control of educational activity of both schoolchildren and students are revealed in the works of A. Aleksyuk, S. Arkhangelsky, Yu. Babansky, V. Bezpalko and others. The issue of control of independent work of students is revealed in the works of B. Yesypov, V. Kazakov, N. Kalashnik, A. Kotova.

Highly appreciating the contribution of scientists to the development of this important problem, we consider it necessary to summarize the experience gained in higher education institutions, which will contribute to its further creative 
use in the educational process, which is the purpose of our study.

Methods and materials of the

study. During the work on the study, such research methods as the method of analysis and synthesis of scientific literature were used to understand the essence of the problem. Sufficient materials were developed to understand the study topic.

Results of the study and their discussion. Effective organization of the educational process, even with motivated students, is impossible without a systematic and properly organized from a pedagogical point of view control, which allows you to assess the performance of each student.

Thus, in accordance with the working curriculum of the discipline "Foreign language (for specific purposes)" for students majoring in "Transport Technology" (road transport) of the National University of Life and Environmental Sciences of Ukraine, the system of assessment of knowledge, skills and abilities of students assessment of all forms of studying the discipline:

- assessment of students' work in the process of practical classes;

- assessment of individual task performance (CR);

- assessment of mastering the issues raised for independent work;

- evaluation of the final control [6].

Let's consider each of the identified sub-items in more detail. Experience has shown that the control of students' academic achievements should take place at every foreign language lesson, because it encourages young people to timely implement the curriculum. Conditionally control of current work of students can be divided into several types:

- preliminary control;

- current control;

- thematic control $[1 ; 3]$.

Note that the preliminary control can be carried out both in the first lesson with students in order to identify the general level of knowledge of a foreign language, and before studying a particular grammatical topic for optimal choice of exercises and adjusting communicative tasks.

Current control is used to reflect students' daily work, their ability and diligence to learn new vocabulary and master grammar. During the control it is necessary to take into account the correctness of the answers, the completeness of the disclosure of educational material and the independence of the task. Moreover, it is necessary to take into account that there are different levels of knowledge acquisition, namely:

- level of understanding;

- level of knowledge;

- level of reproductive action;

- level of productive action;

- level of creative action [3].

Current control can occur in two ways: in the form of frontal control or individual control. Experience has shown that these two forms of control are relevant and necessary, however, each of them has its own characteristics. The advantages of frontal control include its comprehensiveness. During this form of control, the teacher has the opportunity to receive feedback on the academic achievements of all students in a short time.

We agree with the colleagues that frontal control should be used to understand the acquisition of elements of speech. Such control can be performed in both written and oral form, or in a combined form, when the same lexical units the teacher asks first orally to make sure the correct pronunciation of students, and then a dictionary dictation in writing, which allows you to check knowledge of spelling.

As A. Paladieva successfully pointed out, the signs of words, words devoid of specific semantics, are poorly stored in the memory of students, they are easy to confuse with each other when heard. Therefore, regular written control instills linguistic vigilance and accuracy [5]. 
The advantage of frontal control is that it keeps the whole team in suspense, students know that they can be asked at any moment, so the attention of students is focused, thoughts are focused on the work being discussed. Therefore, a faceto-face interview is a more perfect form of verification. However, it also has its drawbacks, which are especially significant in cases where you want to test the skills of students of monologue and dialogic speech.

Therefore, to check the speech in the specialty or reports on the studied, it is necessary to give preference to oral control, because this type of control reflects the correctness and speed of students' speech, their ability to make statements, formulate questions or answer them, maintain conversation during discussion .

Note that one of the advantages of oral control is its organic integration into the classroom, so students do not feel stress during the task. Note that individual control does not involve checking mechanically jagged texts by students, but is integrated into the communicative activities of students. For example, when studying an oral topic "How does an airplane fly" with students, we divide them into groups of two or three people who have to cover the topic. In most cases, we give students complete freedom in choosing the means of disclosing the topic. Some of them prefer oral reports, which are divided into subtopics, while others illustrate speeches with presentations.

Mandatory requirements for students are speaking time and feedback from the rest of the students. This allows you to maintain the attention of the whole group, because the answers to the questions can be awarded additional points or, conversely, removed.

Note that if during the speech the student makes mistakes that do not interfere with the general understanding of the topic, the teacher simply records them and conducts an analysis after the speech of the whole subgroup. In the event that a student systematically mispronounces key words for comprehension, it should be corrected while speaking.

Another type of individual control is to work in pairs or mini groups. In this case, the speaking time of each student increases. Such control should be used to train dialogic speech. During the work of pairs, the teacher moves from one group of students to another, and if necessary, corrects the actions of students. He observes the progress of most couples, joining them as an interlocutor, one or two couples then perform in front of the whole group.

Note that the advantage of such control is that when communicating in a "student-student" format, young people feel more comfortable and are not afraid to make mistakes. On the contrary, they seek to reveal their own communicative potential, there is an atmosphere of "live communication" in a foreign language.

As already mentioned, considerable attention should also be paid to the control of independent work of students, which according to the work program is allocated a third of the total workload of students. The control of students' independent work provides continuous feedback of the teacher with students, allows to see the degree of assimilation of knowledge, skills and abilities by students.

According to the curriculum, the control of independent work includes the following aspects:

1) the degree of assimilation of the theory;

2) the degree of mastering the material of the discipline;

3) acquaintance with the recommended literature, and also with the modern additional literature on the considered questions;

4) the ability to combine theory with practice in consideration

situations when performing tasks assigned for self-study, and

tasks submitted for consideration in the audience; 
5) logic, structure, style of teaching material in written works and speeches in the audience [6].

As aptly noted by $A$. Tsina, to effectively control the independent work of students it is necessary to clearly define the timing of control measures, their content and number, plan in what form will be controlled and develop a system of control measures taking into account the time budget of students [7; 8].

At the end of the semester there is a final control of students' knowledge, which takes place in the form of a test or exam. The test is carried out in writing and consists of three parts: reading a professionally-oriented text in order to obtain the necessary information, grammar and lexical test [6].

Note that the final control in English includes both open (provided questions to which the student must provide a detailed answer) and closed (choose the correct answer) tests.

Criteria-oriented tests, which are created on the basis of logicalpsychological structures and psychological compliance, become especially popular when learning a foreign language. Each task in tests of this type is built on the basis of key concepts and terms that students must learn. The use of criterionoriented tests is effective for both current and final certification of students [4].

We fully agree with the opinion of scientists that to obtain an objective assessment of tests it is advisable:

- divide the test into elements according to the number of tasks;

- evaluate each task with a certain number of points (depending on the complexity of the task);

- determine the total number of points for the test [2; 8].

Despite the great attention to the organization and control of students' academic achievements, we believe that students need to instill skills of self-control, which not only performs the function of control, but also activates their cognitive activity, develops attention and desire for excellence [2, p. 57].

Conclusions and prospects.

Thus, the control of students' academic achievements is a necessary element of the educational process which allows to receive feedback from students to identify educational material that requires additional processing and to summarize the material studied. To achieve the best results, control must be supplemented by self-control.

In the future we plan to cover the approaches to the organization of independent work of students while learning a foreign language in more detail.

\section{References:}

1. Vasiuk O., Maidaniuk N. (2009) Orhanizatsiia kontroliu navchannia studentiv [Assessment of Students' Academic Achievements] Rezhy'm dostupu [mode of access] : www.nbuv.gov.ua/portal/soc_gum/vkp/200 9_5/st_5.pdf

2. Kalashnyk N.H., Vertehel V.L. (2005) Samostiina robota - potuzhnyi zasib suchasnoi osvity i vykhovannia [Self Study as Powerful Means of Modern Education]. Zaporizhzhia. $326 \mathrm{~s}$.
3. Kotova
A.

V.

(2011) Orhanizatsiia kontroliu navchalnoi diialnosti studentiv VNZ pry vyvchenni anhliiskoi movy [University Students' Academic Achievements Control Organisation when Studying English] Vykladannia mov u vyshchykh navchalnykh zakladakh osvity na suchasnomu etapi [Teaching Languages at Higher Institutions]. Vyp. 19. S. 41-47
4. Kushnir
$\mathrm{V}$.

$\mathrm{S}$. (2011) Osoblyvosti kryterialnooriientovanoho testuvannia pry vyvchenni inozemnoi movy profesiinoho spriamuvannia u vyshchii shkoli [Specific Features of Criteria Oriented Tests when Studying Professionally Oriented English in Higher Education Establishments]. Suchasni metody vykladannia iozemnoi movy profesiinoho spriamuvannia $u$ vyshchii shkoli [Modern Methods Specific Purpose Foreign Language Teaching in 
Higher Education Rezhy`m dostupu [mode of access]

http://confesp.fl.kpi.ua/node/1030

5. Paladiieva A. (2015) Formy kontroliu movnoi kompetentnosti studentiv na zaniattiakh $\mathrm{z}$ inozemnoi movy za fakhovym spriamuvanniam [Forms of Language Competence Assessment when Studying English for Specific Purposes]. Problemy pidhotovky suchasnoho vchytelia [Problems of Modern Teacher Training]. № 12. S. $69-76$

6. Robocha prohrama z navchalnoi dystsypliny «Inozemna mova (za profesiinym spriamuvanniam)» Natsionalnoho universytetu bioresursiv i pryrodokorystuvannia Ukrainy (2019). $15 \mathrm{~s}$ [Steering document "Foreign Language (for Specific Purposes). Natioonal University of Life and Environmental Sciences] Rezhy'm dostupu [mode of access] : https://nubip.edu.ua/node/1438/1
7. Tsyna
A
(2005)
Typy

dydaktychnoi vzaiemodii vykladacha i
Didactic Interaction of the Teacher and Students during the Educational Process] Zbirnik naukovih prats Poltavskoho derzh. ped. un-tu [Collection of scientific works of Poltava State Pedagogical University] . Vyp. 7 (46). S. $268-276$.

8. Tsyna A. (2006) Vyznachennia mety i zmistu kontrolnykh zakhodiv za samostiinoiu robotoiu studentiv pry vyvchenni vuzivskykh dystsyplin (Defining the purpose and the Content of Students' Self Study Control when Studying Subjects at University] Zbirnik naukovih prats Poltavskoho derzh. ped. un-tu [Collection of scientific works of Poltava State Pedagogical University]. Vyp. 4 (51). Poltava. S. $69-73$.

9. Cheremska

O.

(2010)

Formuvannia movnoi i komunikatychnoi kompetentsii movnoi osobystosti u vyshchii shkoli [Formation of Language and Communicative Competencies at University]. Vyshcha osvita [Higher Education]. № 12. S. 63 - 72 studentiv u protsesi navchannia [Types of

\section{КОНТРОЛЬ НАВЧАЛЬНИХ ДОСЯГНЕНЬ СТУДЕНТІВ ТЕХНІЧНИХ ФАКУЛЬТЕТІВ ПІД ЧАС ВИВЧЕННЯ АНГЛІЙСЬКОЇ МОВИ Цимбал С.В., Яременко Н. В.}

Анотація. У статті висвітлено підходи до організації контролю навчальних здобутків студентів технічних фракультетів під час вивчення англійської мови та представлено власний досвід щодо його проведення. Установлено, що для ефективної організації навчального процесу необхідно систематично оцінювати роботу студентів як під час практичних занять, так і їх самостійної роботи. Під час педагогічної діяльності встановлено, що під час проведення поточного контролю доцільно організовувати попередній та тематичний контролі. Здійснюючи контроль, необхідно враховувати правильність відповідей, повноту розкриття навчального матеріалу та самостійність виконання завдання. Причому, зауважимо, що існують різні рівні засвоєння знань, а саме: рівень розуміння; рівень пізнання; рівень репродуктивної дії; рівень продуктивної дії; рівень творчої дії. Поточний контроль може відбуватися двома шляхами: у вигляді фронтального контролю або індивідуального контролю, усно або письмово, в залежності від мети перевірки. 3'ясовано, що не менш важлива увага має спрямовуватися на організацію контролю самостійної роботи студентів, яка спрямована на перевірку засвоєння як теоретичних знань, так і роботи із усними темами. До підсумкового контролю з англійської мови включено як відкриті (надаються питання, на які студент має надати розгорнуту відповідь) , так і закриті (вибрати правильний варіант відповіді) mecmu.

Ключові слова: студенти, контроль, поточний контроль, підсумковий контроль. 